\title{
MEMAHAMI INFLUENCER MARKETING: KAJIAN LITERATUR DALAM VARIABEL PENTING BAGI INFLUENCER
}

\author{
Fadhila Hasna Athaya ${ }^{1)}$, Irwansyah ${ }^{2)}$ \\ ${ }^{1}$ Ilmu Komunikasi FISIP, Universitas Indonesia, Jakarta \\ email: fadhila.hasna@ui.ac.id \\ ${ }^{2}$ Ilmu Komunikasi FISIP, Universitas Indonesia, Jakarta \\ email: irwansyah09@ui.ac.id
}

\begin{abstract}
Indonesia has the highest number of ad-blocker application users, which causes marketers to find other ways to reach their target market. Influencer marketing is becoming a popular choice given the high number of social media users and several other factors that support the success of this technique. This research is a literature review of the development of the Influencer Marketing concept over the last three years. The main focus is to find out the variables that support the performance of an influencer. In the findings, the factors most often raised in previous studies are expertise, trustworthiness, credibility, disclosure of sponsors, parasocial relationships, and suitability. As a suggestion for future research, it is necessary to study the rules and ethics for influencers in conducting promotions on their platforms to maintain consumer safety.
\end{abstract}

Keywords: Influencer Marketing, Social Media, Advertising, Engagement

\begin{abstract}
Abstrak
Indonesia merupakan negara dengan jumlah pengguna aplikasi ad blocker tertinggi. Ini menyebabkan pemasar harus mencari cara lain untuk menjangkau target marketnya. Influencer marketing menjadi pilihan yang populer mengingat jumlah pengguna media sosial yang tinggi serta beberapa faktor lainnya yang mendukung keberhasilan teknik ini. Penelitian ini merupakan studi literatur dari perkembangan konsep Influencer Marketing selama 3 tahun terakhir dengan fokus utama untuk memetakan apa saja variabel yang mendukung performa seorang influencer. Dalam temuannya, faktor-faktor yang sering diangkat dalam penelitian adalah expertise, trustworthiness, credibility, sponsorship disclosure, hubungan parasosial, dan congruence. Sebagai saran untuk penelitian mendatang, perlu dikaji bagaimana aturan dan etika bagi para influencer dalam melakukan promosi di platformnya untuk menjaga keamanan konsumen.
\end{abstract}

Kata kunci: Influencer Marketing, Media Sosial, Periklanan, Engagement

\section{PENDAHULUAN}

Pertumbuhan jumlah adopsi internet membuka peluang lebih besar bagi pemasar untuk menjangkau target market mereka dengan lebih masif dan spesifik. Berdasarkan tren penggunaan internet, ada beberapa hal yang menjadi catatan. Indonesia adalah negara dengan tingkat penggunaan aplikasi ad blocker tertinggi di dunia dengan persentase 56,8\% (We Are Social, 2021). Dengan demikian, ada tantangan tambahan bagi pemasar untuk menampilkan iklan produk atau layanan mereka di website-website.
Secara global, berdasarkan We Are Social (2021), alasan untuk menggunakan ad blocker adalah karena ada terlalu banyak iklan di internet (22,3\%), banyak iklan yang mengganggu atau tidak relevan $(22,3 \%)$, melanggar batas privasi $(19,9 \%)$, dan iklan mendominasi layar sebuah website $(16,7 \%)$.

Untuk mengatasi hambatan komunikasi yang berkembang ini untuk menjangkau konsumen secara online, perusahaan berupaya memberikan pengaruh pada konsumen dengan pengemasan pesan yang lebih berakar pada konten (Burgess, 2016; Tapinfluence, 
2016) dan salah satunya adalah melalui media sosial. Dari 274.9 juta penduduk Indonesia, $73.7 \%$ di antaranya adalah pengguna media sosial aktif (APJII, 2020). Di Indonesia, rata-rata durasi penggunaan internet untuk media sosial adalah 3 jam 14 menit per hari dan $65,1 \%$ pengguna menyatakan menggunakan media sosial untuk melakukan riset pada brand (We Are Social, 2021). Terlebih lagi, ditemukan bahwa sumber bagi pengguna internet Indonesia menemukan sebuah merek, selain melalui mesin pencari $(49,7 \%)$, adalah melalui iklan di media sosial $(39,2 \%)$ dan rekomendasi atau komentar di media sosial $(39,2 \%)$.

Di antara banyak strategi pemasaran inovatif yang telah diujicobakan oleh para pemasar, influencer marketing telah menjadi pendekatan yang hemat biaya bagi merek untuk dapat memiliki kontak yang lebih langsung dan organik dengan calon konsumen (Talavera, 2015).

Berdasarkan laporan dari Anymind (2020), ada beberapa tren yang disoroti dalam perkembangan influencer marketing di Indonesia. Secara vertikal, influencer terbanyak ada di sektor Seni \& Hiburan, disusul dengan Fesyen \& Gaya Hidup dan Kecantikan. Kemudian, jumlah influencer terbanyak ada dalam platform Youtube $(53,65 \%)$ dan Instagram $(28,67 \%)$.

Penelitian ini merupakan studi literatur dari perkembangan konsep Influencer Marketing selama tiga tahun terakhir dengan fokus utama untuk menjawab pertanyaan penelitian: apa saja variabel yang mendukung performa seorang influencer?

\section{KAJIAN PUSTAKA}

\section{Konvergensi Media dan Fenomena Influencer dari Kalangan Non-Selebriti}

Selama paruh terakhir abad ke-20, perkembangan media dan budaya utama menyebabkan perkembangan selebritas menjadi semakin berpengaruh ( $\mathrm{Yu}$ et al.,
2014). Perkembangan media sosial baru semakin penting karena memungkinkan sejumlah besar individu yang tidak berbakat/biasa untuk mengejar ketenaran dan mempengaruhi segmen konsumen yang lebih luas (Gountas, Gountas, Reeves \& Moran, 2012; Turner, 2006).

Tayangan reality show di TV menjadi penyelamat banyak jaringan televisi yang mengalami kesulitan keuangan di tahun 90-an karena berhasil menarik banyak penonton dengan biaya produksi yang rendah. (Couldry, 2008 \& Gamson, 2011). Reality show berhasil menarik tidak hanya orang biasa yang mencari ketenaran selama lima belas menit, tetapi juga selebriti yang ingin mendapatkan perhatian media dan meningkatkan peringkat popularitas mereka (Hackley \& Hackley, 2015; Holmes \& Redmond, 2012).

Dengan meningkatnya fragmentasi lanskap media, munculnya platformplatform digital baru, dan juga konvergensi media, dimana internet menjadi tempat orang mencari informasi dan hiburan merek memperhatikan perlunya mempromosikan produk melalui pembuatan iklan viral dan tidak mengganggu di platform media sosial (De Veirman et al., 2017). Media sosial memungkinkan pengguna dan merek untuk menjangkau dan terhubung dengan audiens yang diinginkan dengan lebih baik (Carah, N., \& Shaul, M., 2016).

Di antara para pengguna media sosial, muncul sosok-sosok yang memiliki pengaruh, kemudian disebut sebagai influencer, tampaknya berdampak kuat pada pengambilan keputusan follower mereka. Oleh karena itu, muncullah bernama influencer marketing, sebuah teknik pemasaran bagi pengiklan yang bekerja sama dengan influencer untuk memberikan endorsement atau dukungan pada produk, merek, dan organisasi di profil media sosial mereka (De Veirman, Cauberghe \& Hudders, 2017). Saat ini, 
influencer marketing adalah strategi yang umum digunakan dan menghasilkan perkiraan yang menunjukkan nilai pasar influencer akan mencapai \$ 15 miliar pada tahun 2022 (Business Intelligence, 2019).

\section{Influencer}

Untuk mendapatkan pemahaman mendalam tentang hubungan dari konsumen dan influencer serta peran dari pengaruh sosial yang dimiliki oleh influencer, berikut adalah penjabaran mengenai definisi influencer dalam tiga tahun terakhir.

Tabel 1. Kumpulan Definisi Influencer

\begin{tabular}{|l|l|}
\hline \multicolumn{1}{|c|}{ Sumber } & \multicolumn{1}{|c|}{ Definisi Influencer } \\
\hline $\begin{array}{l}\text { Casalo et } \\
\text { al., 2020 }\end{array}$ & $\begin{array}{l}\text { Pengguna media sosial } \\
\text { terkemuka yang } \\
\text { mengumpulkan pengikut } \\
\text { dengan membuat persona } \\
\text { online yang otentik. }\end{array}$ \\
\hline $\begin{array}{l}\text { Ladhari et } \\
\text { al., 2020 }\end{array}$ & $\begin{array}{l}\text { Pengguna media sosial } \\
\text { terkemuka yang } \\
\text { dipandang sebagai ahli } \\
\text { dalam domain minat } \\
\text { tertentu, seperti mode, } \\
\text { gaya hidup, fotografi, } \\
\text { perjalanan, dan } \\
\text { sebagainya. }\end{array}$ \\
\hline $\begin{array}{l}\text { Ki \& Kim, } \\
\text { 2019 }\end{array}$ & $\begin{array}{l}\text { Influencer dianggap } \\
\text { sebagai pemimpin opini } \\
\text { digital, karena reputasi } \\
\text { mereka sering kali } \\
\text { berasal dari pengetahuan } \\
\text { tentang topik tertentu, } \\
\text { seperti kecantikan atau } \\
\text { mode. }\end{array}$ \\
\hline Audrezet et \\
al., 2018 & $\begin{array}{l}\text { Pengguna media sosial } \\
\text { yang menciptakan } \\
\text { identitas online yang kuat } \\
\text { dengan mengemas dan } \\
\text { mengomunikasikan } \\
\text { narasi pribadi otentik }\end{array}$ \\
\hline
\end{tabular}

\begin{tabular}{|l|l|}
\hline & $\begin{array}{l}\text { yang menggabungkan } \\
\text { foto, video, dan aktivitas. }\end{array}$ \\
\hline $\begin{array}{l}\text { De Veirman } \\
\text { et al., 2017 }\end{array}$ & $\begin{array}{l}\text { Influencer dipandang } \\
\text { sebagai sumber pribadi } \\
\text { dan kredibel yang dapat } \\
\text { dihubungkan dengan } \\
\text { konsumen. }\end{array}$ \\
\hline
\end{tabular}

Influencer secara aktif menyiarkan kehidupan mereka dan berinteraksi erat dengan pengikut mereka untuk mempertahankan status sosial serta identitas merek mereka (Marwick, 2013). Influencer mentransfer makna ke merek dari eksposur produk untuk menceritakan kisah tentang kehidupan dan tujuan mereka yang diungkapkan dalam postingan yang mengandung istilah emosional, kognitif, dan behavioral (Dessart et al., 2015) sehingga menghasilkan kredibilitas, kepercayaan dan daya tarik untuk pesan yang diumumkan secara lebih tinggi (Lim et al., 2017).

Persepsi positif influencer oleh pengikut ini menjadikan pesan mereka sangat efektif dalam hal menciptakan brand impact yang diinginkan (Lou \& Yuan, 2019). Umumnya, pengguna media sosial memandang influencer sebagai sosok yang menarik, otentik, dan mirip dengan mereka (Ki et al., 2020).

Dalam segi jangkauan pada follower, Campbell \& Farrell (2020) membagi influencer dalam beberapa kategori, yaitu: nano-influencer, micro-influencer, macroinfluencer, mega-influencer, dan celebrity influencer. Sementara asal ketenaran celebrity influencer terletak di luar media sosial, jenis influencer lain membangun ketenaran mereka di media sosial.

Perbedaan di antara kategori-kategori ini terletak pada jumlah follower, dengan mega-influencer telah mencapai satu juta follower atau lebih, macro-influencer 
antara 100.000 dan satu juta follower, micro-influencer antara 10.000 dan 100.000, dan nano-influencer dengan jumlah follower lebih kecil dari 10.000 (Campbell \& Farrell, 2020).

Macro-influencer tampaknya menjadi yang teratas di domain spesifik mereka dan memiliki tingkat engagement atau keterlibatan yang lebih kuat dengan pengikut mereka dibandingkan dengan mega-influencer. Micro-influencer lebih terbatas cakupannya secara geografis dan memiliki lebih sedikit kemitraan dengan merek. Namun, skor mereka lebih tinggi pada keaslian dan keintiman dibandingkan dengan macro-influencer, sehingga hal tersebut meningkatkan dampak persuasif mereka. Nano-influencer sering kali berada di tahap awal karier mereka dan memiliki tingkat engagement terkuat dari semua kategori influencer karena audiens mereka yang lebih kecil. Mereka lebih terbuka terhadap kemitraan tidak berbayar untuk membangun profil mereka, dan mereka sering kali menjangkau merek sendiri untuk membina kemitraan (Campbell \& Farrell, 2020).

\section{Influencer Marketing}

Influencer marketing adalah taktik yang digunakan pengiklan dan merek dengan bekerja sama dengan pengguna media sosial individu untuk mempromosikan pesan dan produk merek mereka (IAB, 2018). Kegiatan influencer marketing sebagian besar dilakukan di platform sosial, seperti Instagram, Facebook, dan Twitter (Burgess, 2016).

Influencer marketing dapat didefinisikan sebagai penggunaan influencer, baik selebriti maupun nonselebriti, dengan banyak follower untuk mendorong tanggapan sikap dan perilaku yang positif pada konsumen mengenai minat terhadap merek dengan menggunakan postingan yang dibagikan di platform media sosial, yang juga memungkinkan influencer dan follower untuk berpartisipasi dalam pembuatan bersama brand image di media sosial (Giles \& Edwards, 2018).

Word-of-mouth adalah efek yang ingin diciptakan influencer marketing melalui kerja sama dengan pengguna media sosial dengan kemampuan untuk mempengaruhi perilaku sejumlah besar pengikut mereka (Petrescu et al., 2018). Penggunaan influencer dapat menekan biaya untuk menjangkau khalayak sasaran dan memberikan manfaat yang beragam untuk konten atau pesan yang disampaikan (Childers et al., 2018) dan konsumen melihatnya sebagai lebih dapat diandalkan, pribadi, kurang komersial dan tidak dikendalikan oleh merek, lebih otentik, dan sesuai dengan selera mereka (Forbes, 2019).

Bukan hal baru bahwa seorang awam akan membawa dampak persuasif yang lebih kuat sebagai narasumber dengan daya tarik dan kemiripannya dengan khalayak, sebagaimana dijelaskan oleh literatur Source Credibility (Katz \& Lazarsfeld 1955; McGuire 1985). Namun, efek pendukung dari influencer marketing jauh lebih kompleks daripada konsep tradisional sumber orang awam seperti teman dan keluarga. Karena, walaupun influencer itu jauh secara sosial, namun secara psikologis sedekat 'seseorang seperti saya'. Aspek relasional dari influencer marketing menunjukkan bahwa konsumen mengidentifikasi adanya kemiripan diri mereka dengan influencer dan menganggap influencer sebagai sosok yang lebih dapat diterima daripada selebriti tradisional (Shan, Chen, \& Lin 2020).

Dalam hal laba atas investasi, perusahaan diperkirakan mendapatkan kembali 5 dolar untuk setiap dolar yang diinvestasikan (The Influencer Marketing Hub, 2020). Selain itu, $80 \%$ pemasar menganggap tindakan terkait influencer marketing itu efektif, dan $89 \%$ menunjukkan bahwa ROI sebanding 
dengan, atau bahkan lebih baik daripada, tindakan pemasaran lainnya (Mediakix, 2019).

Ada beberapa tren di pasar yang menjelaskan tentang influencer marketing. Konsumen menggunakan platform sosial secara ekstensif untuk membantu dalam proses keputusan pembelian mereka (De Veirman \& Hudders, 2020). Konsumen mengonsumsi lebih banyak konten yang dihasilkan oleh influencer, dan mereka lebih segan mengonsumsi konten yang dibuat oleh brand (Fink et al., 2019; Müller \& Christandl, 2019). Remaja adalah segmen yang paling daat dipengaruhi influencer dan diharapkan tren di kalangan remaja ini akan terus berlanjut hingga dewasa untuk pembelian di masa mendatang, dan juga akan mempengaruhi komentar dan rekomendasi mereka terhadap produk dan layanan (Forbes, 2019; Lou \& Yuan, 2019).

\section{METODE PENELITIAN}

Penelitian ini dilakukan secara metode kualitatif dengan teknik pengambilan data berupa literature review. Dalam database Taylor \& Francis Online selama 3 tahun terakhir, yaitu 2019-2021, ditemukan ada 28 penelitian dengan kata kunci "influencer marketing". Setelah disortir berdasarkan konteks yang relevan, ada 20 penelitian yang menjadi acuan. Penelitian tersebut berasal dari 15 jurnal, yaitu International Journal of Advertising, Journal of Marketing Management, Journal of Interactive Advertising, Journal of Global Fashion Marketing, Journal of Internet Commerce, Journal of Promotion Management, Current Issues in Tourism, Emerging Markets Finance and Trade, International Journal of Sustainable Development \& World Ecology, Investment Analysts Journal, Journal of Global Scholars of Marketing Science, Journal of International Consumer Marketing, Journal of Relationship
Marketing, dan Studies in Political Economy.

Untuk mengembangkan tinjauan pustaka, peneliti mengikuti langkahlangkah yang direkomendasikan oleh Kitchenham et al. (2009) dan Baumann et al.(2002), yaitu merumuskan pertanyaan penelitian, mengumpulkan materi, menentukan kriteria inklusi, dan menyortirnya dalam beberapa klasifikasi.

\section{HASIL DAN PEMBAHASAN}

4.1 Penelitian Tiga Tahun Terakhir di Taylor Francis dengan Kata Kunci "Influencer Marketing"

4.1.1 The effect of social media on perceived information credibility and decision making (Cooley, D., \& Parks-Yancy, R., 2019)

Penelitian ini menyimpulkan bahwa orang yang dikenal konsumen secara pribadi adalah rujukan yang lebih terpercaya daripada mereka yang bukan, meskipun perujuknya adalah selebritas atau influencer. Penelitian menggunakan metode survei. Saran bagi penelitian mendatang adalah untuk meneliti bagaimana dukungan memengaruhi pembelian produk yang tidak terkait dengan penampilan seseorang.

4.1.2 Investigating consumer engagement with influencer-vs. brand-promoted ads: The roles of source and disclosure (Lou, C., Tan, S. S., \& Chen, X., 2019)

Penelitian ini menyimpulkan bahwa iklan yang dipromosikan influencer memiliki engagement yang jauh lebih tinggi dalam jumlah like dan komentar daripada iklan yang dipromosikan merek di antara merek pakaian di Instagram. Konsumen memiliki persentase sentimen negatif yang jauh lebih tinggi dalam komentar mereka tentang iklan yang dipromosikan merek dan persentase sentimen positif yang lebih rendah 
daripada pada iklan yang dipromosikan influencer. Konsumen menunjukkan apresiasi tinggi untuk produk yang dipromosikan influencer dan menunjukkan involvement tinggi dalam produk yang diiklankan di iklan yang dipromosikan influencer. Penelitian menggunakan metode survei berbasis big data. Saran bagi penelitian mendatang adalah untuk menggunakan desain eksperimen di mana mereka dapat memanipulasi sumber iklan media sosial dan jenis pengungkapan untuk menguji peran influencer dalam keterlibatan perilaku konsumen, sentimen, dan topik dalam komentar mereka.

\subsubsection{Influencer marketing: how message} value and credibility affect consumer trust of branded content on social media (Lou, C., \& Yuan, S., 2019)

Penelitian ini menyimpulkan bahwa nilai informatif dari konten yang dihasilkan oleh influencer, trustworthiness, daya tarik, dan kesamaan dengan follower secara positif mempengaruhi kepercayaan follower pada postingan bermerek influencer, yang kemudian mempengaruhi kesadaran merek dan niat membeli. Penelitian menggunakan metode survei. Saran bagi penelitian mendatang adalah untuk mengidentifikasi kondisi batas kritis atau mekanisme pengaruhnya terhadap pembangunan merek dan perilaku konsumen.

\subsubsection{The commercialization of social media} stars: a literature review and conceptual framework on the strategic use of social media influencers (Hudders, L., De Jans, S., \& De Veirman, M., 2020)

Penelitian ini merupakan kajian literatur sistematis yang meneliti 154 publikasi peer-reviewed terkait influencer marketing dalam database Scopus selama 2018-2020. Tujuannya adalah mensintesis penelitian terdahulu mengenai influencer marketing untuk mendeteksi aliran penelitian, mengidentifikasi celah penelitian, dan membuka jalan untuk penelitian lebih lanjut tentang strategi influencer marketing. Saran bagi penelitian mendatang yang ingin melakukan kajian literatur adalah menggunakan keyword yang lebih beragam untuk menjelaskan influencer media sosial, seperti "online personality" dan "YouTube celebrities".

4.1.5 Influencer marketing on Instagram: How sponsorship disclosure, influencer credibility, and brand credibility impact the effectiveness of Instagram promotional post (Lee, S. \& Kim, E., 2020)

Penelitian ini menyimpulkan bahwa pengungkapan sponsor, kredibilitas influencer, dan kredibilitas merek dapat mempengaruhi keefektifan teknik influencer marketing. Penelitian ini juga memperkaya pemahaman tentang celebrity endorsement dalam hal bagaimana menggunakan selebriti yang tepat di media sosial untuk mencapai tujuan periklanan yang diinginkan. Pengenalan niat komersial oleh konsumen dalam periklanan tidak selalu mengarah pada evaluasi kritis dari pesan iklan. Penelitian menggunakan metode survei. Saran bagi penelitian mendatang adalah untuk melakukan eksperimen di kategori produk lain dan juga dengan segmentasi umur yang lebih beragam.

4.1.6 I like what she's\# endorsing: the impact of female social media influencers' perceived sincerity, consumer envy, and product type (Lee, J. A., \& Eastin, M. S., 2020)

Penelitian ini menyimpulkan bahwa konsumen cenderung memiliki attitude yang lebih baik terhadap influencer dengan sifat ketulusan yang dirasakan tinggi. Penelitian menggunakan metode eksperimen. Saran bagi penelitian mendatang adalah untuk mengeksplorasi jenis hubungan dari konsumen dan influencer dalam memengaruhi persepsi konsumen, menyertakan variabel lain yang memengaruhi penilaian konsumen, dan 
meneliti tidak hanya pada elemen visual, tetapi juga verbal.

\subsubsection{Influencer marketing: brand control, commercial orientation and post credibility (Martínez-López, F. J., et al., 2020)}

Penelitian ini menyimpulkan bahwa kepercayaan pada influencer akan berkurang jika orientasi komersial yang dirasakan posting daripada kontrol merek yang dirasakan dari posting seorang influencer. Kontrol merek yang dirasakan tinggi juga mengurangi kemauan konsumen untuk mencari lebih banyak informasi. Kepercayaan influencer sangat penting dalam memprediksi post credibility, yang kemudian dapat memprediksi minat dan kemauan untuk mencari informasi lebih lanjut. Penelitian menggunakan metode survei. Saran bagi penelitian mendatang adalah untuk meningkatkan hasil reliabilitas dengan menggunakan perwakilan sampel acak dari semua pengguna media sosial, dan juga dengan tidak berfokus pada satu negara juga menggunakan beberapa posting dan / atau media sosial yang berbeda, membuat perbandingan antara sampel yang berbeda, memungkinkan analisis tentang apakah perbedaan muncul tergantung pada konfigurasi postingan atau influencer yang digunakan.

4.1.8 The effect of influencer-product fit on advertising recognition and the role of an enhanced disclosure in increasing sponsorship transparency (De Cicco, R., Iacobucci, S., \& Pagliaro, S., 2020)

Penelitian ini menyimpulkan bahwa ada pengaruh positif influencerproduct fit terhadap attitude, credibility, dan niat berkelanjutan untuk mengikuti influencer. Pengungkapan yang mencolok meningkatkan persepsi transparansi sponsor ketika influencerproduct fit yang lebih tinggi membuat lebih sulit untuk membedakan dukungan asli dari yang disponsori. Penelitian menggunakan metode eksperimen. Saran bagi penelitian mendatang adalah untuk membuka skenario penelitian yang berbeda, yang secara khusus ditujukan untuk menguraikan seberapa banyak kesesuaian yang dirasakan dapat dianggap berasal dari kecocokan antara jenis kelamin influencer dengan jenis kelamin pengguna, dan produk / merek yang mungkin menimbulkan tingkat feminitas dan maskulinitas yang berbeda.

4.1.9 Disclosing sponsored Instagram posts: the role of material connection with the brand and message-sidedness when disclosing covert advertising (De Veirman, M., \& Hudders, L., 2020)

\begin{tabular}{llr}
\multicolumn{2}{r}{ Penelitian ini } & menyimpulkan \\
bahwa menyertakan & pengungkapan \\
sponsor secara negatif & memengaruhi
\end{tabular} brand attitude melalui pengenalan iklan yang ditingkatkan, yang mengaktifkan skeptisisme iklan, yang secara negatif memengaruhi kredibilitas influencer. Brand attitude hanya terpengaruhi secara negatif ketika influencer menggunakan pesan satu sisi dan bukan ketika pesan itu dua sisi. Menyertakan pernyataan bahwa sebuah postingan tidak disponsori, alihalih membiarkan ketidakjelasan apakah postingan mereka disponsori, dapat menghasilkan tanggapan merek yang lebih positif melalui pengakuan iklan dan skeptisisme yang lebih rendah. Penelitian menggunakan metode eksperimen. Saran bagi penelitian mendatang adalah untuk mencoba melihat bagaimana mendiskusikan fitur produk yang negatif dan positif dapat berfungsi sebagai isyarat validasi terhadap kejujuran influencer.

4.1.10 'You really are a great big sister'parasocial relationships, credibility, and the moderating role of audience comments in influencer marketing (Reinikainen, H., Munnukka, J., Maity, D., \& Luoma-aho, V., 2020)

Penelitian ini menyimpulkan bahwa hubungan parasosial dengan influencer membangun kredibilitas influencer yang dirasakan, sementara 
komentar oleh audiens lain memoderasi efeknya. Kredibilitas influencer secara positif memengaruhi brand trust dan niat membeli. Penelitian menggunakan metode survei. Saran bagi penelitian mendatang adalah untuk menguji model konseptual yang disajikan dan pengaturan eksperimental pada layanan lain, merek, dan konteks media sosial untuk memvalidasi hasil ini.

4.1.11 An expert with whom I can identify: the role of narratives in influencer marketing (Feng, Y., Chen, H., \& Kong, Q., 2020)

Penelitian ini menyimpulkan bahwa narasi orang pertama dari influencer dilengkapi dengan kekuatan transportasi narasi membuat kemungkinan bahwa follower tidak akan terpengaruh oleh pengungkapan sponsor. Follower cenderung mengidentifikasi dengan citra profesional dari influencer yang diintegrasikan ke dalam konteks pribadi dan sosial. Penelitian menggunakan metode content analysis dengan machinelearning untuk analisis topik dan deeplearning untuk analisis gambar. Saran bagi penelitian mendatang adalah untuk mengembangkan pengukuran khusus transportasi influencer-follower dan lakukan eksperimen di mana mereka dapat memanipulasi jenis narasi influencer serta melihat persepsi influencer terhadap strategi konten dan teknik bercerita dengan melakukan penelitian kualitatif di antara influencer media sosial teratas untuk mendapatkan perspektif mereka.

4.1.12 Behind influencer marketing: key marketing decisions and their effects on followers' responses (Martínez-López, F. J., Anaya-Sánchez, R., Fernández Giordano, M., \& Lopez-Lopez, D., 2020)

Penelitian ini menyimpulkan bahwa orientasi komersial dari pesan memiliki efek negatif yang kuat pada bagaimana pesan itu dipersepsikan, mengurangi trustworthiness pada pemberi pengaruh, serta mengurangi kredibilitas pesan. Brand control tingkat tinggi menyebabkan kredibilitas pos berkurang, serta minat pengikut berkurang pada merek dan niat yang lebih rendah untuk mencari informasi yang lebih terkait. Influencer harus dianggap oleh follower sebagai pakar produk, atau paling tidak dapat memberikan opini sebagai calon konsumen produk tersebut. Penelitian menggunakan metode eksperimen. Saran bagi penelitian mendatang adalah untuk melakukan eksperimen dengan variabel lainnya.

4.1.13 The effect of influencer marketing on consumers' brand admiration and online purchase intentions: An emerging market perspective (Trivedi, J., \& Sama, R., 2020)

Penelitian ini menyimpulkan bahwa ada keuntungan yang pasti dalam memilih influencer ahli daripada influencer selebriti yang menarik saat merencanakan komunikasi pemasaran produk elektronik pada konsumen. Penelitian menggunakan metode survei. Saran bagi penelitian mendatang adalah untuk melakukan survei pada kategori produk lain, memilih segmentasi lain sebagai subjek penelitian, seperti gen $\mathrm{z}$ atau masyarakat dengan budaya berbeda, dan meneliti dengan variabel lainnya.

4.1.14 Online engagement and the role of digital influencers in product endorsement on Instagram (Silva, et al., 2020)

Penelitian ini menyimpulkan bahwa platform digital memungkinkan berbagai bentuk keterlibatan dengan membuat konfigurasi baru yang memengaruhi pemasaran hubungan dan strategi promosi. Endorsement mencerminkan para influencer dan karakteristik mereka, semakin baik penerimaan dan efisiensi komunikatif yang sama, yang menghasilkan lebih banyak engagement. Penelitian menggunakan metode kualitatif berupa analisis semiotika. Saran bagi penelitian mendatang adalah untuk melakukan riset langsung dengan influencer dan pengikut mereka melalui wawancara dan FGD untuk lebih memperdalam masalah 
engagement dan melakukan studi lintas budaya untuk memverifikasi interaksi antara influencer dan pengikut mereka berdasarkan perbedaan budaya antar negara. Selain itu, juga dapat melakukan studi kuantitatif untuk memverifikasi dampak influencer digital terhadap perilaku pembelian konsumen, serta melakukan analisis kemungkinan perbedaan tingkat engagement antara pria dan wanita sebagai pengikut influencer digital.

\subsubsection{Fake ads: The influence of counterfeit} native ads on brands and consumers (Grigsby, J. L., 2020)

Penelitian ini menyimpulkan bahwa persepsi konsumen tentang iklan palsu dan nyata bervariasi berdasarkan pengalaman media sosial pengguna. Penelitian menggunakan metode eksperimen. Saran bagi penelitian mendatang adalah untuk melakukan observasi terhadap perilaku di media sosial.

\subsubsection{Effect of Social Media Influencer Marketing on Consumers' Purchase Intention and the Mediating Role of Credibility (Saima \& Khan, A.K., 2021)}

Penelitian ini menyimpulkan bahwa trustworthiness, kualitas informasi, dan entertainment value memiliki dampak langsung yang signifikan terhadap kredibilitas dari influencer dan juga dampak tidak langsung yang signifikan terhadap niat pembelian. Penelitian menggunakan metode survei. Saran bagi penelitian mendatang adalah untuk menggunakan metode kualitatif untuk mengidentifikasi atribut influencer lain yang memengaruhi niat beli konsumen, atau menyelidiki pengaruh influencer marketing pada aspek lain seperti brand awareness, brand admiration, consumer engagement, dan brand image.

4.1.17 Keeping up with influencers: exploring the impact of social presence and parasocial interactions on Instagram (Kim, H., 2021)

Penelitian ini menyimpulkan bahwa social presence dan interaksi parasosial adalah prediktor utama dari influencer marketing yang sukses, namun keduanya dapat menimbulkan kekhawatiran karena dapat menghalangi konsumen untuk mengembangkan pengetahuan persuasi yang akurat. Penelitian menggunakan metode eksperimen. Saran bagi penelitian mendatang adalah untuk meneliti interaksi antara konsumen dan influencer secara natural, bukan dengan eksperimen dan meneliti hubungan konsumen dan influencer yang sama jenis kelaminnya, karena berdasarkan Social Identity Theory (individu dengan kesamaan jenis kelamin dapat memiliki hubungan yang lebih kuat).

4.1.18 The impact of social media influencers on travel decisions: The role of trust in consumer decision journey (Pop, R. A., Săplăcan, Z., Dabija, D. C., \& Alt, M. A., 2021)

Penelitian ini menyimpulkan bahwa kepercayaan konsumen pada influencer memiliki dampak positif pada setiap fase pengambilan keputusan dalam traveling, yaitu hasrat, pencarian informasi, mengevaluasi informasi, keputusan pembelian, kepuasan, dan pembagian pengalaman. Penelitian menggunakan metode survei. Saran bagi penelitian mendatang adalah untuk mempertimbangkan untuk menerapkan faktor lain yang dapat mempengaruhi pengambilan keputusan perjalanan, mis. kontrol perilaku yang dirasakan, faktor demografi, kualitas layanan yang dirasakan, loyalitas, dll.

\subsection{Pembahasan}

Saat ini adalah era mass-self communication (Castell, 2010). Setiap orang bisa menyuarakan pendapat di 
media sosial. Konsumen bisa mendapatkan banyak alternatif kanal untuk mendapatkan informasi. Konten yang didapatkan sangat terpersonalisasi. Algoritma media sosial yang membaca perilaku kita terhadap sebuah konten, dapat memprediksi konten yang sesuai dan menyajikannya di hadapan kita.

Saat kita mempercayai sebuah sumber, kita akan cenderung tidak mempertanyakan kembali apakah informasi yang disajikan itu valid atau tidak. Dengan bermunculannya banyak influencer di media sosial, merekalah yang menjadi gatekeeper dari informasi apa yang dapat mencapai pada audiens mereka. Melalui penelitian ini, telah dipetakan apa saja faktor-faktor yang menjadi perhatian dari konsumen atau audiens pada seorang influencer.

Ada beberapa hasil penemuan yang disarankan menjadi perhatian utama bagi para influencer untuk dapat secara efektif memberikan manfaat dan juga pengaruh sehingga membawa solusi terbaik bagi berbagai pihak, yaitu expertise, trustworthiness, credibility, sponsorship disclosure, hubungan parasosial, dan congruence.

Berdasarkan 18 artikel jurnal yang telah disortir berdasarkan kebutuhan dan kesesuaian konteks, penelitian ini membagi penemuan dari setiap artikel jurnal dalam beberapa bagian.

\section{Expertise}

Pesan yang menarik secara visual, bergengsi, dan informatif dan yang menyampaikan expertise atau keahlian influencer dalam domain tersebut secara positif memengaruhi niat word-of-mouth (eWOM) elektronik dan niat membeli melalui kepemimpinan selera dan opini serta keinginan mimikri (Ki \& Kim, 2019). Keahlian tersebut meliputi keakraban, pemahaman dan pengalaman yang diperoleh seseorang dengan terus bekerja di bidang ilmu yang sama. Untuk dianggap sebagai seorang ahli, seorang komunikator perlu mendapat informasi yang baik tentang suatu topik, memiliki keterampilan yang dibutuhkan dalam melakukan sesuatu, atau memiliki gelar yang memiliki reputasi (Gass \& Seiter, 2011).

\section{Trustworthiness}

Trustworthiness atau kepercayaan dari sumber adalah "persepsi penerima 'dari sumber sebagai jujur, tulus, atau jujur" (Giffin, 1967). Kepercayaan, kualitas informasi dan nilai hiburan memiliki pengaruh langsung yang kuat terhadap kredibilitas influencer dan pengaruh tidak langsung yang kuat terhadap niat beli konsumen (Saima \& Khan, 2021).

\section{Credibility}

Seiring dengan influencer menambah nilai pada merek, produk, atau layanan, credibility atau kredibilitas influencer telah dianggap sebagai anteseden paling penting untuk efektivitas periklanan (Keller, 2005). Bahkan dalam situasi di mana konsumen mengenali maksud periklanan dari pos promosi dan menolak persuasi, menggunakan influencer yang sangat kredibel dapat membantu konsumen untuk memiliki sikap positif terhadap merek (Sternthal et al., 1978).

Kredibilitas influencer sebagai sumber informasi-produk sangat kuat karena konsumen menganggap influencer lebih terkait dan dekat secara sosial dibandingkan dengan selebriti tradisional (Djafarova \& Rushworth, 2017). Authenticity yang tinggi ditambah dengan keahlian yang tinggi dapat menjelaskan mengapa beberapa influencer lebih populer dan sukses daripada yang lain, terutama dalam hal membujuk orang lain, karena kredibilitas sumber tampaknya menjadi faktor penting dalam menjelaskan persuasif konten bersponsor (Wellman et al. 2020). Kredibilitas terdiri dari beberapa dimensi - seperti daya tarik, keahlian, dan kepercayaan dari pemberi dukungan (Chu 
\& Kamal, 2008). Keahlian mengacu pada kemampuan yang dirasakan dari suatu sumber untuk mengetahui subjek, kepercayaan mengacu pada kejujuran yang dirasakan dan kepercayaan dari sumber, dan daya tarik mengacu pada keakraban yang dirasakan dan disukai dari sumber (McCracken, 1989).

\section{Sponsorship Disclosure}

Menambahkan pengungkapan sponsor (\#sponsor) ke posting Instagram dari seorang influencer menghasilkan pengakuan iklan yang lebih tinggi dibandingkan dengan posting yang tidak diungkapkan, yang pada gilirannya meningkatkan skeptisisme, mengurangi kredibilitas influencer, dan dengan demikian menurunkan sikap merek (De Veirman \& Hudders, 2020). Sementara pengungkapan berdampak negatif pada kredibilitas influencer ketika dukungan produk hanya menyoroti atribut produk yang positif, tidak ada perbedaan antara posting yang diungkapkan dan yang tidak diungkapkan ketika pengesahan menyoroti atribut produk positif dan negatif.

Pengungkapan sponsor sederhana yang ditambahkan ke posting blog menurunkan kredibilitas sumber dan penerimaan pesan ke tingkat yang lebih besar daripada pengungkapan yang menekankan bahwa influencer memberikan pendapat jujurnya atau tidak ada kondisi pengungkapan; Namun, ini hanya berlaku untuk konsumen yang sangat skeptis (Hwang \& Jeong, 2016). Kondisi pengungkapan yang berbeda tidak berbeda dalam hal kredibilitas sumber maupun penerimaan pesan untuk responden yang kurang skeptis. Sisi pesan (atau penyertaan argumen positif dan negatif dalam pesan) tidak berinteraksi dengan kondisi pengungkapan tetapi berinteraksi dengan skeptisisme di mana sikap merek lebih tinggi untuk pesan dua sisi, dibandingkan dengan pesan satu sisi, ketika responden sangat skeptis, sedangkan efeknya berbalik untuk responden yang skeptisisme rendah.

\section{Hubungan Parasosial}

Responden menunjukkan hubungan parasosial yang lebih kuat ketika postingan tersebut menyertakan beberapa pembaruan tentang peristiwa kehidupan sehari-hari influencer selain konten bermerek, yang menguatkan penelitian sebelumnya bahwa kehadiran sosial membantu meningkatkan hubungan psikologis dengan interaksi yang dimediasi (Jin, Muqaddam \& Ryu 2019; Lee \& Jang 2013). Influencer yang membangun hubungan parasosial yang kuat dengan pengikutnya lebih persuasif serta influencer yang mempromosikan konten bersponsor yang sesuai dengan keahliannya (Hudders, et al., 2020).

Hubungan parasosial dapat dibangun dengan sering memposting pembaruan, memberi pengikut mengintip kehidupan pribadi mereka, dan secara aktif berinteraksi dengan pengikut.

\section{Congruence}

Congruence atau kesesuaian antara influencer dan merek, serta identifikasi parasosial, memengaruhi sikap terhadap merek, keterlibatan, dan niat membeli (Shan et al., 2020)

Kesesuaian yang dirasakan mewakili salah satu mekanisme mendasar utama untuk memunculkan sikap dan hasil perilaku terkait iklan yang positif (De Veirman, Cauberghe, \& Hudders, 2017). Dalam literatur sponsorship, kesesuaian telah diteliti dalam advertorial (Wang \& Li, 2017), sponsorship sosial (Simmons \& Becker-Olsen, 2006), dan advergames (Hernandez et al. 2004). Sebagian besar studi ini menyelidiki bagaimana respons psikologis positif dipengaruhi oleh beberapa jenis kesesuaian antara konteks dan iklan dalam kaitannya dengan aspek tertentu (Moorman, Neijens, \& Smit, 2002). 


\section{SIMPULAN}

Indonesia merupakan negara dengan jumlah pengguna aplikasi ad blocker tertinggi. Ini menyebabkan pemasar harus mencari cara lain untuk menjangkau target marketnya. Influencer marketing menjadi pilihan yang populer mengingat jumlah pengguna media sosial yang tinggi serta beberapa faktor lainnya yang mendukung keberhasilan teknik ini. Dalam temuannya, faktor-faktor yang sering diangkat dalam penelitian adalah expertise, trustworthiness, credibility, sponsorship disclosure, hubungan parasosial, dan congruence.

Di Amerika Serikat, FTC mewajibkan influencer untuk mengungkapkan hubungannya dengan merek untuk melindungi konsumen dari pesan iklan tersemat (Federal Trade Commission, 2017). Indonesia belum memiliki aturan yang secara jelas terkait tata cara seorang influencer dalam mengemas pesan promosinya.

Sebagai saran untuk penelitian mendatang perlu dikaji bagaimana aturan dan etika bagi para influencer dalam melakukan promosi di platformnya untuk menjaga keamanan konsumen. Walaupun seorang influencer menguasai faktorfaktor yang menjadi perhatian audiens, penting untuk mereka mengikuti aturan dari bagaimana pengemasan materi itu tidak membawa dampak negatif atau bahkan menipu audiens.

\section{UCAPAN TERIMAKASIH}

Dengan telah selesainya penulisan artikel ilmiah ini, saya mengucapkan terima kasih kepada penerbit jurnal, para sahabat, advisor kehidupan saya @ndorokakung dan@motulz, bos saya Pak Adhi, dan para reviewer serta semua pihak yang telah membantu, memberikan pandangan, saran, dan kritik untuk terwujudnya tulisan artikel ilmiah saya ini.

\section{DAFTAR PUSTAKA}

Audrezet, A., de Kerviler, G., \& Moulard, J. G. (2020). Authenticity under threat: When social media influencers need to go beyond selfpresentation. Journal of business research, 117, 557-569.

Burgess, E. (2016). 11 essential stats for influencer marketing in 2016. Retrieved February 04, 2018, from http://www.ion.co/11-essentialstats-for-influencer-marketing-in$\underline{2016}$

Campbell, C., \& Farrell, J. R. (2020). More than meets the eye: The functional components underlying influencer marketing. Business Horizons, 63(4), 469-479.

Carah, N., \& Shaul, M. (2016). Brands and Instagram: Point, tap, swipe, glance. Mobile Media \& Communication, 4(1), 69-84.

Casaló, L. V., Flavián, C., \& IbáñezSánchez, S. (2020). Influencers on Instagram: Antecedents and consequences of opinion leadership. Journal of Business Research, 117, 510-519.

Castells, M. (2010). Communication power: Mass communication, mass self-communication, and power relationships in the network society. Media and society, 25(5), 3-17.

Lou, C., \& Yuan, S. (2019). Influencer marketing: how message value and credibility affect consumer trust of branded content on social media. Journal of Interactive Advertising, 19(1), 58-73.

Childers, C. C., Lemon, L. L., \& Hoy, M. G. (2018). \#Sponsored \#Ad: Agency perspective on influencer marketing campaigns. Journal of Current Issues \& Research in Advertising, 40(3), 258274. 
https://doi.org/10.1080/10641734.2 018.1521113

Chu, S. C., \& Kamal, S. (2008). The effect of perceived blogger credibility and argument quality on message elaboration and brand attitudes: An exploratory study. Journal of interactive Advertising, 8(2), 26-37.

Couldry, N. (2008). Reality TV, or the secret theater of neoliberalism. The Review of Education, Pedagogy, and Cultural Studies, 30(1), 3-13.

Cooley, D., \& Parks-Yancy, R. (2019). The effect of social media on perceived information credibility and decision making. Journal of Internet Commerce, 18(3), 249-269.

Dessart, L., Veloutsou, C., \& Morgan-Thomas, A. (2015). Consumer engagement in online brand communities: a social media perspective. Journal of Product \& Brand Management.

De Cicco, R., Iacobucci, S., \& Pagliaro, S. (2020). The effect of influencer-product fit on advertising recognition and the role of an enhanced disclosure in increasing sponsorship transparency. International Journal of Advertising, $1-27$.

De Veirman, M., \& Hudders, L. (2020). Disclosing sponsored Instagram posts: the role of material connection with the brand and message-sidedness when disclosing covert advertising. International journal of advertising, 39(1), 94130.

De Veirman, M., Cauberghe, V., \& Hudders, L. (2017). Marketing through Instagram influencers: the impact of number of followers and product divergence on brand attitude. International journal of advertising, 36(5), 798-828.
Djafarova, E., \& Rushworth, C. (2017). Exploring the credibility of online celebrities' Instagram profiles in influencing the purchase decisions of young female users. Computers in Human Behavior, 68, 1-7.

Feng, Y., Chen, H., \& Kong, Q. (2020). An expert with whom i can identify: the role of narratives in influencer marketing. International Journal of Advertising, 1-22.

Fink, M., Koller, M., Gartner, J., Floh, A., \& Harms, R. (2019). Effective entrepreneurial marketing on Facebook - A longitudinal study. Journal of Business Research. https://doi.org/10.1016/j.jbusres.201 8.10 .005

Martínez-López, F. J., AnayaSánchez, R., Fernández Giordano, M., \& Lopez-Lopez, D. (2020). Behind influencer marketing: key marketing decisions and their effects on followers' responses. Journal of Marketing Management, 36(7-8), 579-607.

Martínez-López, F. J., AnayaSánchez, R., Esteban-Millat, I., Torrez-Meruvia, H., D'Alessandro, S., \& Miles, M. (2020). Influencer marketing: brand control, commercial orientation and post credibility. Journal of Marketing Management, 1-27.

Gamson, J. (2011). The unwatched life is not worth living: The elevation of the ordinary in celebrity culture. Pmla, 126(4), 1061-1069.

Gass, R. H., \& Seiter, J. S. (2011). Credibility. Persuasion: Social influence and compliance gaining, 72-90.

Giles, D. C., \& Edwards, L. (2018). Instagram and the rise of the social media 'influencer'. Twenty-first century celebrity: Fame in digital culture. Emerald Publishing Limited. 
Gountas, J., Gountas, S., Reeves, R. A., \& Moran, L. (2012). Desire for fame: scale development and association with personal goals and aspirations. Psychology \& Marketing, 29(9), 680-689.

Grigsby, J. L. (2020). Fake ads: The influence of counterfeit native ads on brands and consumers. Journal of Promotion Management, 26(4), 569592.

Hackley, C., \& Hackley, R. A. (2015). Marketing and the cultural production of celebrity in the era of media convergence. Journal of marketing management, 31(5-6), 461-477.

Hwang, Y., \& Jeong, S. H. (2016). "This is a sponsored blog post, but all opinions are my own": The effects of sponsorship disclosure on responses to sponsored blog posts. Computers in Human Behavior, 62, 528-535.

Holmes, S., \& Redmond, S. (2012). Framing celebrity: New directions in celebrity culture. Routledge.

IAB. 2018. INSIDE INFLUENCE... Why publishers are increasingly turning to influencer marketing and what that means for marketers inside influence: Influencer marketing for publishers guide. New York. https://www.iab.com/wpcontent/uploads/2018/01/IAB_Influ encer Marketing for Publishers 2 018-01-25.pdf.

Trivedi, J., \& Sama, R. (2020). The effect of influencer marketing on consumers' brand admiration and online purchase intentions: An emerging market perspective. Journal of Internet Commerce, 19(1), 103-124.

Lee, J. A., \& Eastin, M. S. (2020). I like what she's\# endorsing: the impact of female social media influencers' perceived sincerity, consumer envy, and product type. Journal of Interactive Advertising, 20(1), 76-91.

Katarina Halvorsen (2019) A retrospective commentary: How fashion blogs function as a marketing tool to influence consumer behavior: Evidence from Norway, Journal of Global Fashion Marketing, 10:4, 398-403, DOI: 10.1080/20932685.2019.1645035

Katz, E., and P.F. Lazarsfeld. 1955. Personal influence: The part played by people in the flow of mass communications. Glencoe, IL: The Free Press.

Keller, K.L. (2005), "Choosing the right brand elements and leveraging secondary associations will help marketers build brand equity", Marketing Management, Vol. 14 No. 5, pp. 19-23

Ki, C. W. C., \& Kim, Y. K. (2019). The mechanism by which social media influencers persuade consumers: The role of consumers' desire to mimic. Psychology \& Marketing, 36(10), 905-922.

Ki, C. W. C., Cuevas, L. M., Chong, S. M., \& Lim, H. (2020). Influencer marketing: Social media influencers as human brands attaching to followers and yielding positive marketing results by fulfilling needs. Journal of Retailing and Consumer Services, 55, 102133.

Kim, H. (2021). Keeping up with influencers: exploring the impact of social presence and parasocial interactions on Instagram, International Journal of Advertising, DOI:10.1080/02650487.2021.18864 77

Ladhari, R., Massa, E., \& Skandrani, H. (2020). YouTube vloggers' popularity and influence: The roles of homophily, emotional attachment, 
and expertise. Journal of Retailing and Consumer Services, 54, 102027.

Lee, E. J., \& Jang, J. W. (2013). Not so imaginary interpersonal contact with public figures on social network sites: How affiliative tendency moderates its effects. Communication Research, 40(1), 27-51.

Lee, S. \& Kim, E. (2020) Influencer marketing on Instagram: How sponsorship disclosure, influencer credibility, and brand credibility impact the effectiveness of Instagram promotional post, Journal of Global Fashion Marketing, 11:3, 232-249, DOI: 10.1080/20932685.2020.1752766

Lim, X. J., Radzol, A. F., Cheah, J., \& Wong, M. W. (2017). The impact of social media influencers on purchase intention and the mediation effect of customer attitude. Asian Journal of Business Research, 7(2), 19-36. doi:10.14707/ajbr.170035

Lou, C., Tan, S. S., \& Chen, X. (2019). Investigating consumer engagement with influencer-vs. brand-promoted ads: The roles of source and disclosure. Journal of Interactive Advertising, 19(3), 169186.

Hernandez, M. D., Chapa, S., Minor, M. S., Maldonado, C., \& Barranzuela, F. (2004). Hispanic attitudes toward advergames: A proposed model of their antecedents. Journal of Interactive advertising, 5(1), 74-83.

Hudders, L., De Jans, S., \& De Veirman, M. (2020). The commercialization of social media stars: a literature review and conceptual framework on the strategic use of social media influencers. International Journal of Advertising, 1-49.
Lou, C., \& Yuan, S. (2019). Influencer marketing: how message value and credibility affect consumer trust of branded content on social media. Journal of Interactive Advertising, 19(1), 58-73.

Marwick, A. E. (2013). Status update: Celebrity, publicity, and branding in the social media age. Yale University Press.

McCracken, G. (1989). Who is the celebrity endorser? Cultural foundations of the endorsement process. Journal of Consumer Research, 16(3), 310-321. https://doi.org/10.1086/209217

McGuire, W.J. (1985). Attitudes and attitude change. Handbook of social psychology, ed. G. Lindzey and E. Aronson, 233-346. New York: Random.

MediaKix. 2019. Marketing To Teens? Influencers May Be Your Best "Only" Shot. https://mediakix.com/blog/marketin g-to-teens-gen-z-influencers/ (diakses pada Juni 19, 2021).

Moorman, M., Neijens, P. C., \& Smit, E. G. (2002). The effects of magazine-induced psychological responses and thematic congruence on memory and attitude toward the ad in a real-life setting. Journal of Advertising, 31(4), 27-40.

Müller, J., \& Christandl, F. (2019). Content is king - But who is the king of kings? The effect of content marketing, sponsored content \& user-generated content on brand responses. Computers in Human Behavior, 96 (July), 46-55. https://doi.org/10.1016/j.chb.2019.0 2.006

Pop, R. A., Săplăcan, Z., Dabija, D. C., \& Alt, M. A. (2021). The impact of social media influencers on travel decisions: The role of trust in 
consumer decision journey. Current Issues in Tourism, 1-21.

Reinikainen, H., Munnukka, J., Maity, D., \& Luoma-aho, V. (2020). 'You really are a great big sister'parasocial relationships, credibility, and the moderating role of audience comments in influencer marketing. Journal of Marketing Management, 36(3-4), 279-298.

Saima \& Khan, A.K. (2021) Effect of Social Media Influencer Marketing on Consumers' Purchase Intention and the Mediating Role of Credibility, Journal of Promotion Management, 27:4, 503-523, DOI: 10.1080/10496491.2020.1851847

Silva, M. J. D. B., Farias, S. A. D., Grigg, M. K., \& Barbosa, M. D. L. D. A. (2020). Online engagement and the role of digital influencers in product endorsement on Instagram. Journal of Relationship Marketing, 19(2), 133-163.

Simmons, C. J., \& Becker-Olsen, K. L. (2006). Achieving marketing objectives through social sponsorships. Journal of marketing, 70(4), 154-169.

Shan, Y., Chen, K. J., \& Lin, J. S. (2020). When social media influencers endorse brands: the effects of self-influencer congruence, parasocial identification, and perceived endorser motive. International Journal of Advertising, 39(5), 590610.

Sternthal, B., Dholakia, R., \& Leavitt, C. (1978). The persuasive effect of source credibility: Tests of cognitive response. Journal of Consumer research, 4(4), 252-260.

Talavera, M. (2015), "10 Reasons Why Influencer Marketing Is the Next Big Thing," Adweek, July 14, http://www.adweek.com/digital/10reasons-why-influencer-

Tapinfluence. (2016). The future of influencer marketing. 6 predictions your brand or agency can bank on. Retrieved February 04, 2018, from https://www.tapinfluence.com/tp_re source/6-influencer-marketingpredictions-brand-agency-can-bank/ Turner, G. (2006). The mass production of celebrity: 'Celetoids', reality TV and the 'demotic turn'. International journal of cultural studies, 9(2), 153-165.

Wang, Y., \& Li, Y. (2017). Understanding "native advertising" from the perspective of communication strategies. Journal of Promotion Management, 23(6), 913-929.

We Are Social. (2021). Digital 2021. Diakses melalui situs: https://datareportal.com/reports/digi tal-2021-indonesia

Weinswig, D. (2016). Influencers are the new brands. Forbes Media LLC. Retrieved June 19, 2021, from https://www.forbes.com/sites/debor ahweinswig/2016/10/05/influencers -are-the-newbrands/\#7f31c7307919

Wellman, M. L., Stoldt, R., Tully, M., \& Ekdale, B. (2020). Ethics of authenticity: social media influencers and the production of sponsored content. Journal of Media Ethics, 35(2), 68-82. 